Open Access

Review Article
Res. Agric. Livest. Fish.

Vol. 3, No. 1, April 2016: 121-126

\title{
TRANSBOUNDARY DISEASES OF ANIMALS: CONCERNS AND MANAGEMENT STRATEGIES
}

\section{Ariful Islam*}

Department of Medicine, Faculty of Veterinary Science, Bangladesh Agricultural University, Mymensingh-2202, Bangladesh

*Corresponding author: M. Ariful Islam; E-mail: maislam77@bau.edu.bd

\section{ARTICLE INFO ABSTRACT}

Received

20.03.2016

Accepted

24.04.2016

Online

30 April 2016

Key words

Livestock health, Global challenge,

Transboundary animal disease

(TAD),

Global trade,

Management

strategy
Transboundary animal diseases (TADs) are greatly contagious epidemic diseases that can spread very rapidly, irrespective of national borders. They cause high rates of death and disease in animals, thereby having serious socio-economic and sometimes public health consequences while constituting a steady threat to the livelihoods of livestock farmers. With the development of technology, livestock production has gained an integral position in the national economy, socioeconomic development, poverty alleviation and nutrition supply for human. Livestock farming is one of the important sources of livelihood to rural peoples in Bangladesh. A healthy livestock is pleasure of any country including Bangladesh. However, rapid trend of globalization has brought upon challenges in maintaining healthy herds of livestock. The emerging infections of foreign origin could spread across national geographical borders and cause devastation in livestock population. As a result, there will be an emergence and spread of new disease in the region which was once free from the disease. Regional and international approaches have to be followed, and the FAO and OIE Global framework-TADs initiative provides the suitable concepts and objectives as well as an organizational framework to link international and regional organizations at the service of their countries to better prevent and control the risks on animal and human health and the economic impact of TADs and emerging animal diseases. In this paper, we have summarized the main diseases of livestock that are transboundary in nature, and sum up the challenges and necessary management strategies in controlling the transboundary diseases.

To cite this article: Islam MA, 2016. Transboundary diseases of animals: Concerns and management strategies. Res. Agric. Livest. Fish. 3 (1): 121-126.

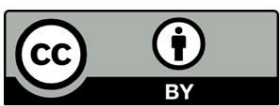

This is an open access article licensed under the terms of the Creative Commons Attribution 4.0 International License

www.agroaid-bd.org/ralf, E-mail: editor.ralf@gmail.com 


\section{INTRODUCTION}

Transboundary animal diseases (TADs) pose a serious risk to the world animal agriculture and food security and jeopardize international trade. The world has been facing devastating economic losses from major outbreaks of TADs. It is unimaginable to have a human society without a healthy population of livestock. Livestock not only provide food security but also improve the quality of human life and make a significant contribution to national economy. Several thousands of small and marginal farmers in the country depend solely on agricultural farming and livestock husbandry. The existence of infectious diseases affecting farm animals has been historically recorded for over hundreds of years. However, factors associated with modernization of human societies such as changes in agro-ecological conditions and global marketing, have led to increased incidences of animal diseases. This is mainly due to spread of disease causing pathogens across borders. With increasing movement of human population, livestock and livestock products, fish and fish products, and plants and plant products within and across countries, together with climate changes, threat from transboundary diseases is intensifying. Transboundary diseases are highly contagious and have the potential for rapid spread, irrespective of national borders, causing serious socioeconomic consequences (Otte et al., 2004). Traditionally, trade, traffic and travel have been instruments of disease spread. Now, changing climate across the globe is adding to the misery. Climate change is creating new ecological platform for the entry and establishment of pests and diseases from one geographical region to another (FAO, 2008). Several new transboundary diseases emerge, and old diseases reemerge, exhibiting increased chances for unexpected spread to new regions, often over great distances.

Transboundary livestock diseases such as Foot-and-mouth disease (FMD) have a direct economic impact by reducing agricultural and animal production (FAO/OIE, 2004; Domenech et al., 2006). Apart from causing suffering and mortality in susceptible population, the diseases adversely affect food safety, rural livelihoods, human health and international trade. Therefore, it is necessary to effectively manage the transboundary diseases. In developing countries, control of these diseases is a key pathway for poverty alleviation. It is advisable to have an effective quarantine system in place to prevent entry and establishment of transboundary diseases. As a second line of defense, a country must also have in place a suitable contingency plans to respond quickly to high threat diseases (Basagoudanavar and Hosamani, 2013). This could be achieved by timely application of scientific technology for rapid response. A disease outbreak in the neighboring country should always be taken as an immediate threat. Thus, it's a big challenge in managing and controlling TADs without collective and collaborative action between neighboring countries.

\section{TRANS-BOUNDARY ANIMAL DISEASES (TADs)}

Transboundary animal diseases are permanent global threat for livestock farmers. TADs are defined as:

"Those that are of significant economic trade and/or food security importance for a considerable number of countries: which can easily spread to other countries and reach epidemic proportions; and where control management, including exclusion requires cooperation between several countries".

Within theses definition, there are many diseases that cause damage and destruction to farmers' property, may threaten food security, injure rural economies, and potentially disrupt trade relations.

The common ways of introduction of animal diseases to a new geographical location are through entry of live diseased animals and contaminated animal products. Other introductions result from the importation of contaminated biological products such as vaccines or germplasm or via entry of infected people (in case of zoonotic diseases). Even migration of animals and birds, or natural spreading by insect vectors or wind currents, could also spread diseases across geographical borders. All animal diseases have the potential to adversely affect human populations by reducing the quantity and quality of food, other livestock products (hides, skins, fibers) and animal power (traction, transport) that can be obtained from a given quantity of resources and by reducing people's assets. Of these, transboundary animal diseases tend to have the most serious consequences. TADs may be defined as those epidemic diseases which are highly contagious or transmissible and have the potential for very rapid spread, irrespective of national borders, causing serious socio-economic and possibly public health consequences. These diseases which cause a high morbidity and mortality in susceptible animal populations, constitute a constant threat to the livelihood of livestock farmers. 
Furthermore, their potential consequences are of such a magnitude that their occurrence may also have a significant detrimental effect on national economies. TADs have the potential to:

- Threaten food security through serious loss of animal protein and/or loss of draught animal power for cropping;

- Increase poverty levels particularly in poor communities that have a high incidence dependence on livestock farming for sustenance;

- Cause major production losses for livetsock products such as meat; milk and other dairy products; wooland other fibers and skins and hides, thereby reducing farm incomes. They may also restrict opportunities for upgrading the production potential of local livestock industries by making it difficult to utilise exotic high producing breeds which tend to be very susceptible to the transboundary disease;

- Add significantly to the cost of livestock production through the necessity to apply costly disease control measures;

- Seriously disrupt or inhibit trade in livestock and livestock products either within a country or internationally. Their occurrence may thereby cause major losses in national export income in significant livestock-producing countries;

- Cause public health consequences in the case of those transboundary animal diseases which can be transmitted to humans (i.e. zoonoses);

- Cause environmental consequences through die-offs in wildlife populations in some cases, and;

- Cause pain and suffering for affected animals.

The most common TADs (Otte et al., 2004; FAO/OIE, 2004) under this category are provided in Table 1.

Table 1: Major Trans-boundary Animal Diseases.

\begin{tabular}{|l|l|l|}
\hline Disease & Animals affected & Regions with major incidence \\
\hline $\begin{array}{l}\text { Foot-and-mouth disease } \\
\text { (FMD) }\end{array}$ & $\begin{array}{l}\text { Cattle, buffalo, sheep, } \\
\text { goats and pigs }\end{array}$ & $\begin{array}{l}\text { Parts of Africa, Middle East and } \\
\text { Asia }\end{array}$ \\
\hline $\begin{array}{l}\text { Peste des petits ruminants } \\
\text { (PPR) }\end{array}$ & Sheep and goats & Africa, Middle East and Asia \\
\hline Classical swine fever (CSF) & Pigs & South and South-East Asia \\
\hline African swine fever (ASF) & Pigs & $\begin{array}{l}\text { Sub-Saharan Africa, West Africa, } \\
\text { parts of Europe and Latin America }\end{array}$ \\
\hline Blue tongue (BT) & Sheep, cattle & $\begin{array}{l}\text { Australia, USA, Africa, Middle } \\
\text { East, Asia and Europe }\end{array}$ \\
\hline Rift Valley Fever (RVF) & Sheep, cattle and goats & Africa \\
\hline $\begin{array}{l}\text { Contagious bovine } \\
\text { pleuropneumonia (CBPP) }\end{array}$ & Cattle & $\begin{array}{l}\text { Eastern, Southern and West Africa, } \\
\text { parts of Asia }\end{array}$ \\
\hline Lumpy skin disease (LSD) & Cattle & Africa \\
\hline $\begin{array}{l}\text { Sheep and goat pox spongiform } \\
\text { Bovine Equine } \\
\text { encephalopathy (BSE) }\end{array}$ & Cheep and goats & $\begin{array}{l}\text { South Asia, China, Middle East, } \\
\text { Africa }\end{array}$ \\
\hline $\begin{array}{l}\text { Venezuelan } \\
\text { Encephalomyelitis }\end{array}$ & UK and other parts of Europe \\
\hline Newcastle disease (ND) & Poultry & $\begin{array}{l}\text { Central American and South } \\
\text { American countries }\end{array}$ \\
\hline $\begin{array}{l}\text { Highly pathogenic avian } \\
\text { influenza (HPAI) }\end{array}$ & Poultry & Asia and Africa \\
\hline Hendra virus (HeV) infection & Horses & Asia, Europe and Africa \\
\hline Nipah virus (NiV) infection & Pigs & Australia \\
\hline
\end{tabular}




\section{CHALLENGES IN DEALING WITH TADs}

TADs are permanent threat for livestock keepers. They have major economic implications: both through the private and public costs of the outbreak, and through the cost of the measures taken at individual, collective and international levels in order to prevent or control infection and disease outbreaks. Several challenges confront the strategies to combat TADs (FAO, 2008; Hitchcock et al., 2007). The major ones are presented below:

- Requirement of novel systems having capacity of real-time surveillance of emerging diseases. For this, need driven research and service oriented scientific technology are a necessary at regional levels. Research emphasis has to be on specific detection and identification of the infectious agents;

- Need for epidemiological methods to assess the dynamics of infections in the self and neighboring countries/regions. These methods should be of real-time utility;

- Need for research and development of disease diagnostic reagents those do not need refrigeration (cold chain). More importantly, they should be readily available as well as affordable, for use in pen-side test format;

- There are many diseases for which there is inadequate supply of vaccines or there are no vaccines available. Insufficient or lack of vaccine hampers the disease control programs. Need to build up vaccine banks for stockpiling the important vaccines to implement timely vaccination;

- Required availability of cost-effective intervention or disease control strategies. Even if a technology is available, it has to be cheaper to adopt at the point of use;

- Need for ensuring public awareness of epidemic animal diseases. Many farmers are unaware of the emerging diseases. As such, unless reported to concerned regional authority, an emerging disease may go unnoticed;

- Shortage of government and private funding for research on emerging animal disease problems. Government as well as industries dealing with animal health should take initiative and appropriate sponsorship in this regard, and;

- Inadequate regulatory standards for safe international trade of livestock and livestock products. Otherwise, there would be a compromised situation in disease control strategies.

\section{Management strategies of TADs}

\section{FAO animal disease emergency response mechanisms (FAO, 2008)}

The FAO Emergency Prevention System (EMPRES) Animal Health develops strategies for intervention and improved management. It works to monitor and give early warning and ultimately to prevent animal diseases.

The Emergency Centre for Transboundary Animal Diseases (ECTAD) is FAO's corporate centre for the planning and delivery of veterinary assistance to FAO member countries responding to the threat of transboundary animal health crises.

The Crisis Management Centre-Animal Health is FAO's rapid response unit to animal disease emergencies. For example, highly Pathogenic Avian Influenza - bird flu. Since 2004 FAO has been at the forefront of the fight against highly pathogenic avian influenza (HPAI) - bird flu - in over 95 countries. FAO has mobilized over US\$ 445 million to combat influenza and emerging disease threats through prevention, surveillance, and control.

Various strategies need to be implemented to prevent and control trans-boundary diseases regionally and internationally. These include:

- Preventing incidence of trans-boundary diseases and disease transmitting vectors. Minimizing the movement of animals across the borders is essential. Also, prompt practice of quarantine 2013 protocol would reduce many transboundary diseases. Geographic information system (GIS) and remote sensing could be utilized as early warning systems and in the surveillance and control of infectious diseases (Martin et al., 2007); 
- Reducing man-made disasters that have adverse implications on climate. Global warming and climate change either due to natural or anthropogenic influences are likely to predispose the animal population to newer infections (FAO, 2008). Therefore collective efforts are needed to minimize adverse climatic changes;

- Interrupting the human-livestock wildlife transmission of infections. Diseases at the wildlife-livestock interface must become the focus for surveillance of emerging infectious diseases (Siembieda et al., 2011). Breaking the cycle of disease transmission would help control the spread of infections;

- Establishing regional biosecurity arrangement with capacity for early disease warning system for surveillance, monitoring and diagnosis of emerging disease threats (Domenech et al., 2006);

- Undertaking animal breeding strategies to create disease resistant gene pools. Enhancing host genetic resistance to disease by selective breeding of resistant animals is a smart strategy to improve natural immunity of animals to counter invading infections (Gibson et al., 2005);

- Strengthening government policies to enhance agricultural/animal research and training, and technology development (Rweyemamu et al., 2006). More funds need to be allocated for this purpose to build goal oriented research programs in combating TADs;

- Ensuring appropriate preparedness and response capacity to any emerging disease. Keeping in view that emerging infectious diseases are a constant threat, it is necessary to have early disease detection capacity and then implement a timely response (Hitchcock et al., 2007);

- Intensification of international cooperation in preventing spread of TADs. As TADs are a concern globally, cumulative effort is needed at international level to minimize the spread of infectious diseases across the borders (Domenech et al., 2006; Hitchcock et al., 2007).

\section{SUMMARY}

Effective TAD management and control is possible, and has been achieved by several countries in the World including two Asian countries (Japan and Korea), to do so it is highly dependent on national governance effective veterinary services and political support. Improved veterinary services and strong regional networks and have the choice to improve their own leadership and management. It is within the control of a veterinary service to develop a TAD control strategy and operational plans. Furthermore, these might be added to increase the capacity indicators such as: a strong relationship with commercial operators, NGOs and civil society; mechanisms for overcoming the constraints to TAD control posed by decentralisation; innovative financing mechanisms backed up by accountability and transparency; continued development of professionals in public and private service; and strong regional collective efforts. With rapidly increasing globalization, an associated risk of movement of trans-boundary diseases is emerging. Trans-boundary animal diseases represent a serious threat. They reduce production and productivity, disrupt local and national economies, and also threaten human health. This imposes extensive challenges for agricultural scientists on the critically important need to improve technologies in animal production and health in order to make sure the food security, poverty alleviation and to aid economic growth. Considering that livestock rearing constitutes a significant share in the national economy of a developing country like ours, it is imperative to take up disease control initiatives. Measures are required to safeguard the livestock industry from epidemics of infectious diseases and to uphold safe international trade of livestock and their products. In this regard, it is essential to develop scientific and risk-based standards that facilitate the international trade in animal commodities. There is also a need for information on regional movements of animals, birds and poultry products, in order to plan regional strategies of TADs control.

\section{REFERENCES}

1. Basagoudanavar $\mathrm{SH}$ and $\mathrm{M}$ Hosamani, 2013. Trans-boundary Diseases of Animals: Mounting Concerns, VetScan, Vol. 7, No. 2.

2. Domenech J, Lubroth J, Eddi C, Martin V, Roger F, 2006. Regional and international approaches on prevention and control of animal trans-boundary and emerging diseases.

3. FAO, 2008. Expert meeting on climate related trans-boundary pests and diseases including relevant aquatic species. FAO headquarters, 25-27 February 2008. Rome, Italy. 
4. FAO/OIE, 2004. Joint FAO/OIE initiative. The global framework for the progressive control of trans-boundary animal diseases (GF-TADs).

5. Gibson JP and Bishop SC, 2005. Use of molecular markers to enhance resistance of livestock to disease: A global approach. OIE Sci. Technolgy Review, 24: 343-353.

6. Hitchcock P, Chamberlain A, Van Wagoner M, Inglesby TV and O'Toole T, 2007. Challenges to global surveillance and response to infectious disease outbreaks of international importance. Biosecurity and Bioterrorism, 5: 206-227.

7. Martin V, De Simone L, Lubroth J, 2007. Geographic information systems applied to the international surveillance and control of trans-boundary animal diseases, a focus on highly pathogenic avian influenza. Veterinaria Italiana, 43: 437-450.

8. Otte MJ, Nugent and McLeod A, 2004. Trans-boundary animal diseases: Assessment of socio-economic impacts and institutional responses. Livestock policy discussion paper No. 9. FAO, Rome, Italy.

9. Rweyemamu MM, Musiime J, Thomson G, Pfeiffer D and Peeler E, 2006. Future control strategies for infectious animal diseases-Case study of the UK and sub-Saharan Africa. In: UK Government's foresight project, Infectious diseases: preparing for the future, pp 1-24.

10. Siembieda JL, Kock RA, McCracken TA and Newman SH, 2011. The role of wildlife in trans-boundary animal diseases. Animal Hlth. Research Reviews, 12: 95-111. 